\title{
Cytotoxicity studies of membranes made with cellulose nanofibers from fique macrofibers
}

\author{
S. F. Souza ${ }^{1,3}$, A. L. Leao ${ }^{2}$, C. B. Lombello ${ }^{4}$, M. Sain ${ }^{3}$, and M. Ferreira ${ }^{1, *}$ \\ ${ }^{1}$ Centro de Ciências Naturais e Humanas, UFABC - Universidade Federal do ABC, Av. dos Estados, 5001, Santo André, SP 09210-580, \\ Brazil \\ ${ }^{2}$ Department of Bioprocess and Biotechnology, São Paulo State University (UNESP), Rua José Barbosa de Barros, 1780, Botucatu, \\ SP 18610-307, Brazil \\ ${ }^{3}$ Center for Biocomposites and Biomaterials Processing, Faculty of Forestry, University of Toronto, 33 Willcocks St, Toronto, \\ ON M5S3B3, Canada \\ ${ }^{4}$ Centro de Engenharia, Modelagem e Ciências Sociais Aplicadas, UFABC, Av. dos Estados, 5001, Santo André, SP 09210-580, Brazil
}

Received: 16 May 2016

Accepted: 31 October 2016

Published online:

18 November 2016

(C) Springer Science+Business Media New York 2016

\begin{abstract}
We report on the fabrication of cellulose nanofibers from Fique (Furcraea andina), in which raw macrofibers were chemically treated and then ground. Bleaching was effective in removing lignin from the raw fibers, and this was confirmed with distinct techniques, viz. X-ray diffraction, FTIR spectroscopy, thermogravimetric analysis, and the estimation of the kappa number. From scanning electron microscopy and transmission electron microscopy images, the nanofibers were seen to form a network with $85 \%$ of nanofibers having diameters smaller than $50 \mathrm{~nm}$, while their length was hundreds of nanometers. The tensile strength of membranes made with the nanofibers was $166 \mathrm{MPa}$. These membranes had no cytotoxicity in in vitro indirect tests analyzed qualitatively and quantitatively. Indeed, cell viability was higher for the nanofibers than the negative control.
\end{abstract}

\section{Introduction}

The interest in renewable resources has increased in many strategic areas, including in materials sciences where natural fibers can be employed in composites, though so far this has been mostly in handcrafts or products with low added value [1,2]. The majority of the natural fibers contains cellulose, which is an abundant, cheap, and renewable biopolymer. With proper processing, cellulose may exhibit high mechanical strength due to its crystalline structure [3], while contributing to increase the tensile strength, Young's modulus, and impact strength of composites [4]. Applications of cellulose nanofibers are now envisaged in the automobile industry, in aircrafts, electronics, packaging, and in the biomedical industry [5-7]. Various processes involving chemical and mechanical treatments are used to obtain cellulose, depending on the source and composition $[3,8]$, during which other components of natural fibers are removed, especially hemicellulose, lignin, ashes, and pectins. After isolation, microstructured cellulose has to undergo another process for nanofibers to be produced,

Address correspondence to E-mail: mariselma.ferreira@ufabc.edu.br 
the most common being chemical [9, 10], enzymatic [11], and mechanical $[7,12]$ processes.

In this study, we used a chemical-mechanical process to obtain nanofibrillated cellulose from Fique (Furcraea andina), which is originally from Peru. Fique is a promising natural material because the macrofibers extracted from its leaves have high mechanical strength (Delvasto et al. 2010). Nanofibers from fique were obtained here by chemical treatments, followed by the pulping and bleaching treatment through an oxidative pathway, and being later mechanically processed. Raw macrofibers, bleached microfibers, and nanofibers were characterized with X-ray diffraction (XRD), Fourier transform infrared spectroscopy (FTIR), and thermogravimetric analysis. In addition, we show that the nanofibers may be biocompatible based on in vitro cytotoxicity tests.

\section{Materials and methods}

Fique macrofibers, originally from the Sao Paulo State, Brazil, were obtained from a genetic bank at the Rural Engineering Department of the São Paulo State University (Unesp). To obtain cellulose nanofibers, the fique macrofibers were milled and sieved through a 4-mm mesh, and then dried at $60{ }^{\circ} \mathrm{C}$ overnight. The dried macrofibers were treated with $0.05 \mathrm{~N} \mathrm{HCl}$ solution for $2 \mathrm{~h}$ at $70{ }^{\circ} \mathrm{C}$ to remove extractives such as oil and waxes, to which a $\mathrm{NH}_{4} \mathrm{OH}$ solution was added until reaching $\mathrm{pH}$ 9.5. A time lapse of $12 \mathrm{~h}$ was taken to extract pectic substances. The macrofibers were then washed until reaching the same $\mathrm{pH}$ of distilled water. The pulping process followed, with $4 \% \mathrm{NaOH}$ solution (1:10) at $70{ }^{\circ} \mathrm{C}$ for $2 \mathrm{~h}$, after which the macrofibers were washed again. In order to remove all of the non-cellulosic substances, the macrofibers were bleached using $800 \mathrm{~mL}$ of distilled water, $8.6 \mathrm{~mL}$ of acetic acid, and $9 \mathrm{~g}$ of $\mathrm{NaOCl}_{2}$ per each $100 \mathrm{~g}$ of dried pulp. This reaction was kept for $4 \mathrm{~h}$ at approximately $70{ }^{\circ} \mathrm{C}$. The bleached microfibers from fique were processed mechanically using the commercial grinder (Supermasscolloider MKZA 10-15 J, Masuko Sangyo Co., Japan), in a process repeated for 9,12 , or 15 times.

\section{Membrane procedure}

Membranes were prepared through filtration of $0.3 \mathrm{~g}$ of nanofibers suspension under vacuum using a polysulfone filter of $0.1 \mu \mathrm{m}$ pore. The resulting membrane was covered with another polysulfone filter and then compressed at 50 psi for 30 min between paper sheets at room temperature and dried completely at $55^{\circ} \mathrm{C}$ overnight.

\section{Characterization}

\section{Mechanical strength of fique macrofibers}

The mechanical strength was measured according to ASTM D3822- “Tensile Test for single Textile Fibers” using an Instron 5582 instrument and Blue Hill software. The macrofibers were segregated in single macrofibers whose diameter was measured in five different points using optical microscopy. The average diameter was used to calculate the tensile strength for ten distinct macrofibers. The gap between the grips was $2.5 \mathrm{~cm}$ and the speed was $1 \mathrm{~mm} / \mathrm{s}$ with a load of $1000 \mathrm{~N}$.

\section{Tensile strength of nanofiber membranes}

The tensile strength of ten membranes made with nanofibers was measured with an Instron Model 20 using the speed of $2.5 \mathrm{~mm} / \mathrm{min}$ with load cell of $2 \mathrm{kN}$ following the standard procedure ASTM-D638 [13]. The thickness of each sample was measured with a caliper rule.

\section{Chemical analysis}

The chemical composition of fique fibers was determined as to their contents of cellulose, hemicellulose, and lignin following the TAPPI standard [14]. First, the holocellulose was determined according to TAPPI $\mathrm{T} 19 \mathrm{~m}-54$, which consists in selective degradation of lignin, thus yielding the contents of cellulose and hemicellulose. For these procedures, fique fibers were dried, milled in 200 mesh, and then treated with a solution of sodium hypochlorite and glacial acetic acid at $75{ }^{\circ} \mathrm{C}$ under magnetic stirring for $2 \mathrm{~h}$. Holocellulose was filtered and washed with hot water (at nearly $100{ }^{\circ} \mathrm{C}$ ) and acetone, and dried at $60^{\circ} \mathrm{C}$ in an oven until constant weight. The lignin content was calculated from the subtraction between the initial weight of fique fibers and holocellulose content. To determine the cellulose content, sodium hydroxide solution $17.5 \mathrm{wt} \%$ was added to holocellulose previously dried at room temperature, under magnetic stirring for $30 \mathrm{~min}$ to eliminate hemicellulose. Cellulose was filtered and washed until neutral $\mathrm{pH}$ and then dried at $60^{\circ} \mathrm{C}$ in an 
oven, until constant weight. Then, the hemicellulose content was determined from the subtraction between holocellulose and cellulose contents.

\section{Microscopic study and diameter size}

Scanning electron microscopy (SEM) was used to examine the microstructure of fique raw fibers and bleached fibers using a Jeol JSM-6610 LV instrument and a FEI-Quanta FEG 650 at LNANO (Brazilian Nanotechnology National Laboratory at CNPEM, Campinas, Brazil), while the nanofibers were analyzed using transmission electron microscopy (FEIQuanta FEG 250) at the Centre For Nanostructure Imaging from Department of Chemistry at University of Toronto. For SEM analyses, untreated fibers and bleached fibers were placed on top of a carbon film on the stubs and coated with a thin layer of gold to make electrical contact. For TEM analyses, the nanofiber suspension was cast on a 400-mesh copper grid and dried. The diameter of the nanofibers was estimated using Image J program, with the size scale calibrated with the scale bar on SEM and TEM images. The diameter distribution was obtained by measuring the diameter of 50 nanofibers.

\section{FTIR spectroscopy}

FTIR spectroscopy was used to identify chemical groups of untreated fique fibers, bleached fibers, and nanofibers with a Bruker Tensor 27. The samples were dispersed in $\mathrm{KBr}$ and the spectra were taken with 32 scans in the range between 4000 and $400 \mathrm{~cm}^{-1}$.

\section{Thermogravimetric analysis (TGA)}

The thermal stability of raw fique macrofibers, bleached microfibers, and nanofibers was investigated with a TGA Q500 V6.7 Build 203 instrument under nitrogen, with heating from 25 to $600{ }^{\circ} \mathrm{C}$ at $10{ }^{\circ} \mathrm{C} \mathrm{min}{ }^{-1}$. The derivative of the mass loss curves allowed us to determine the components before and after treatment on the macrofibers.

\section{$X R D$ and Crystallographic Study}

The cellulose nanofibers' crystallinity was determined from the diffraction patterns measured with a Philips Analytical X-ray PW 1830 diffractometer $(45 \mathrm{kV}$, $100 \mathrm{~mA}$ ) equipped with $\mathrm{Cu} \mathrm{K} \alpha$ radiation $(\lambda=0.1541 \mathrm{~nm})$. The angular range varied from 10 to $40^{\circ}(2 \theta)$ and the step size was $0.02^{\circ}(2 \theta)$. The crystallinity index of the macrofibers, microfibers, and nanofibers was calculated using an empirical method proposed by Segal et al. (1959), which measures the relative crystallinity of native cellulose, using Eq. (1) [15].

C.I. $=\frac{I_{002}-I_{\mathrm{am}}}{I_{002}} \times 100$,

where C.I. is the relative crystallinity index; $I_{002}$ is the maximum diffraction intensity at the main peak around $22.5^{\circ}(2 \theta)$; and $I_{\mathrm{am}}$ is the diffraction intensity of the amorphous material at the peak of approximately $18^{\circ}(2 \theta)$, where the intensity is minimal.

\section{Kappa number}

The estimation of the kappa number serves to assess the relative bleachability or the degree of delignification of the pulp [16]. In other words, it is a measure of the bleaching treatment efficiency. The definition by TAPPI (Technical Association of the Pulp and Paper Industry) reads: “Kappa number gives essentially a straight line relationship with the total lignin content in pulps that can be estimated fairly closely by rapid, indirect methods by oxidation of the lignin (TAPPI T236 Kappa Number of Pulp)." The procedure described in T236 cm-85 from TAPPI standard was applied on raw fique fibers before and after the bleaching process and nanofibers. According to this standard, kappa is the number of volume $(\mathrm{mL})$ consumed of $20 \mathrm{mmol} / \mathrm{L}(0.1 \mathrm{~N}) \mathrm{KMnO}_{4}$ solution by one gram of moisture-free pulp under the conditions specified in the standard.

\section{Biological assay}

The cytotoxicity assay for the nanofibers (NFs) was performed based on ISO standards (ISO 10993-5) using a Vero cell lineage (ATCC CCL-81). The cells were cultured with HAMF10 medium, 10\% fetal calf serum, and $1 \%$ antibiotics at $\mathrm{pH}$ 7.4. The cells were maintained at $37{ }^{\circ} \mathrm{C}$ and $5 \% \mathrm{CO}_{2}$. The membranes of cellulose nanofibers were prepared using the same procedure as described above, and cut into pieces of $1 \mathrm{~cm}^{2}$. These samples were sterilized in alcohol at $70^{\circ}$ for $12 \mathrm{~h}$ and exposed to ultraviolet light for $30 \mathrm{~min}$. For the cytotoxicity assay, the membranes were incubated in $5 \mathrm{~mL}$ culture medium for $24 \mathrm{~h}$, for the nanofiber extract preparation. 
Figure 1 a Photograph of fique plant. $\mathbf{b}$ Raw macrofibers mechanically extracted from the leaves. $\mathbf{c}$ and $\mathbf{d}$ SEM images from the raw macrofibers and bleached microfibers, respectively. e and $\mathbf{f}$ TEM images of cellulose nanofibers.
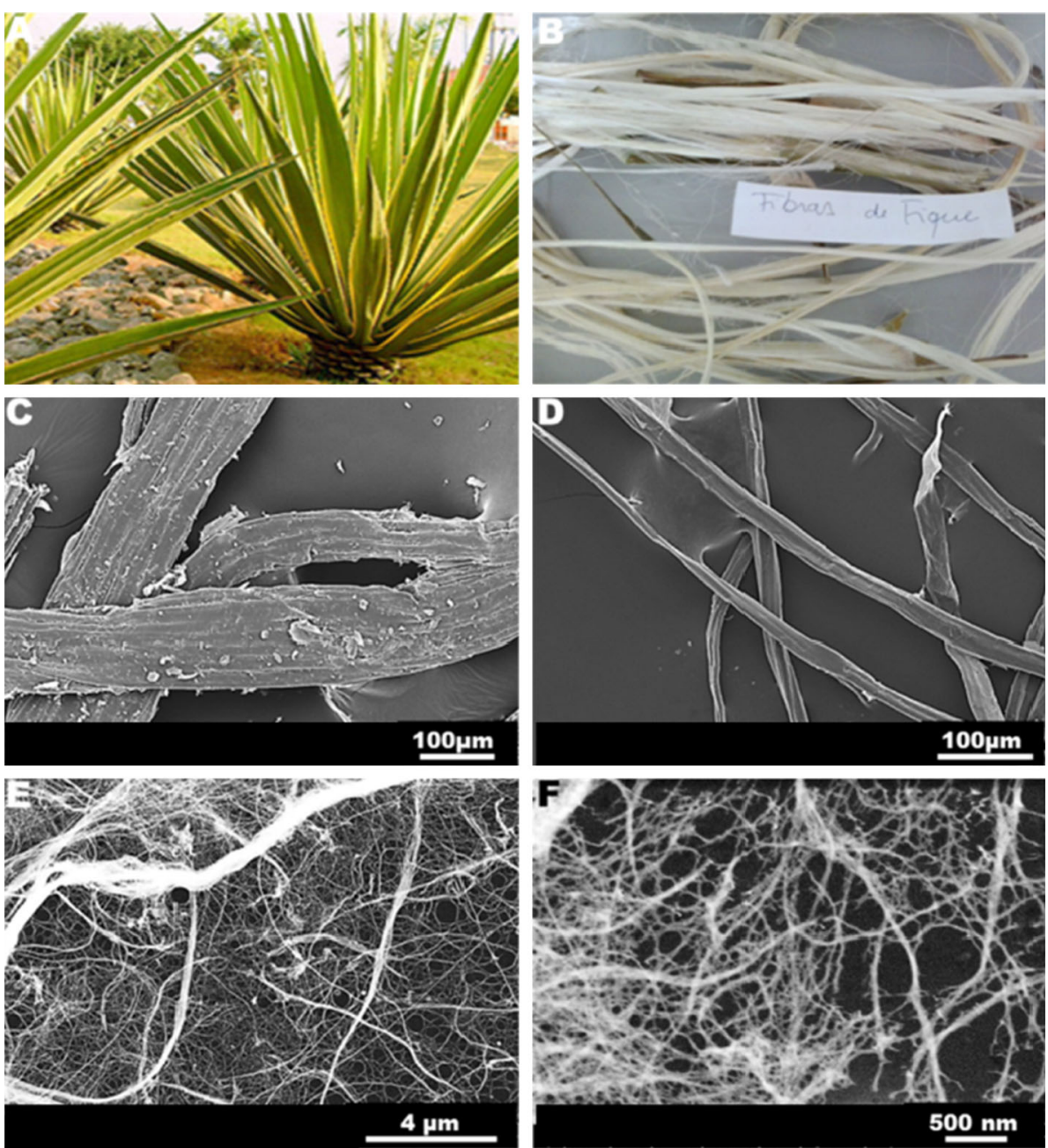

Indirect cytotoxicity-quantitative assay

The quantitative analyses of viable cells were made with MTT ([3-(4,5-Dimethylthiazol-2-yl)-2,5Diphenyltetrazolium Bromide]) assay [17, 18]. Vero cells were seeded at the density of $10^{4}$ cells/well, in 96-well cell culture plates. The cells were incubated for $24 \mathrm{~h}$ until confluence. On the second day, the culture medium was replaced by the nanofiber extracts and the cells were incubated for $24 \mathrm{~h}$ in the presence of these extracts. The medium was removed after the incubation period, replaced by $10 \mu \mathrm{L}$ of MTT ( $5 \mathrm{mg}$ / $\mathrm{mL}$ ), and prepared in phosphate buffer. The cultures were then incubated for $4 \mathrm{~h}$ at $37^{\circ} \mathrm{C}$. The formazan crystals were solubilized with $50 \mu \mathrm{L}$ of sterile DMSO. After $30 \mathrm{~min}$, absorbance was measured in an Elisa reader at $570 \mathrm{~nm}$ (Spectramax M5). Balk wells with standard culture medium were used as negative control, while the positive control had $0.25 \%$ phenol. The assay was performed in quintuplicate.

\section{Morphological evaluation}

The cells cultured in nanofibers extract were observed after 24-h incubation at a phase-contrast microscope (AxioVert A1, Zeiss) and analyzed with AxioVison SE64 (Zeiss) program. After initial observation, the extracts were removed and the adhered cells were fixed with glutaraldehyde $2.5 \%$ in phosphate buffer for $20 \mathrm{~min}$, followed by washing with water and $0.15 \%$ toluidine blue staining for $30 \mathrm{~min}$.

\section{Results and discussion}

Figure 1a shows a photograph of a fique plant, and raw macrofibers extracted mechanically from the leaves are shown in Fig. 1b. SEM image from the raw macrofibers is shown in Fig. 1c. The bleaching process causes the diameter of the macrofibers, of the order of $100 \mu \mathrm{m}$, to be reduced to $15-25 \mu \mathrm{m}$, and are 


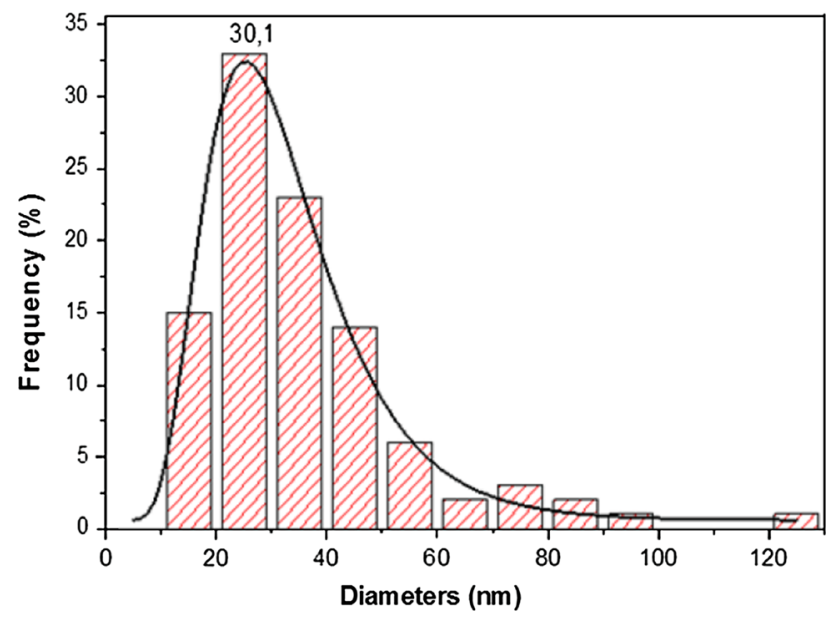

Figure 2 Histogram with distribution of diameters for the nanofibers obtained from TEM images.

called here bleached microfibers which is shown as the SEM image in Fig. 1d. This reduction in diameter for the bleached microfiber is caused by the removal of compounds, including lignin and hemicellulose, with the release of bundles of microfibers that compose macrofibers in natural plants [19]. The concept that macrofibers in nature are composed of microfibers has been supported by different authors. For instance, the morphology of microfibrillar elements is believed to affect the macroscopic properties [20], and the elementary fibrils can be considered as individual units [21]. The presence of elementary fibrils with a hexagonal closely packed arrangement has been confirmed with small-angle X-ray scattering [22], and their diameter has been reported to vary from 10 to $50 \mathrm{~nm}$ [23].

The nanofibers obtained from the shearing promoted by the grinder form a network structure similar to that of bacterial cellulose where nanofibers are interconnected, as shown on TEM images of Fig. 1e, f.
The distribution of diameters of the nanofibers in Fig. 2 peaks around $30 \mathrm{~nm}$. Because the nanofibers are several nanometer-to-micrometers long, they may be also referred to as microfibrillated or nanofibrillated cellulose. Similar samples of nanocellulose have been reported from raw materials such as soy hulls [24], rice husks, hemp, wood [13], and Curaua $[25,26]$.

The average tensile strength of a single natural macrofiber, without any treatment, was $320 \pm 59 \mathrm{MPa}$, being significantly higher than the value reported in the literature for fique, which is $197 \pm 65$ [14] and $237 \pm 51 \mathrm{MPa}$ [27]. This large difference is probably due to the variability of material properties from natural sources, as they may depend on the location, climate, nutrients, period of extraction, and extraction process, in addition to the use of modifiers $[23,28]$. The membranes made with nanofibers are transparent as shown in Fig. 3a. The tensile strength for the nanofibers' membranes in Fig. $3 \mathrm{~b}$ increased with the number of grindings, where the maximum strength was $166.2 \pm 10.4 \mathrm{MPa}$ for nanofibers ground 15 times. The lower tensile strength for the nanofibers' membranes, compared to the macrofibers, may be associated with the removal of components that act as binders and impart high strength to the macrofibers. The strength of the fique nanofibers' membranes reported here is considerably higher than the $65 \mathrm{MPa}$ for nanofibers from Curaua [25, 28] and the $102 \mathrm{MPa}$ for Aloe Vera [29]. The Curaua nanofibers were prepared with different equipments called homogenizer but similar nanofibrillated structure, while those from Aloe Vera were obtained with a similar process of bleaching and grinding as for the fique nanofibers studied here. Since wood nanofibers have been reported to reach $240 \mathrm{MPa}$ of maximum tensile strength [13], it may be
Figure 3 a The nanofiber membrane; $\mathbf{b}$ the average of maximum tensile strength measured for ten membranes prepared with nanofibers ground 9,12 and 15 times. (a)

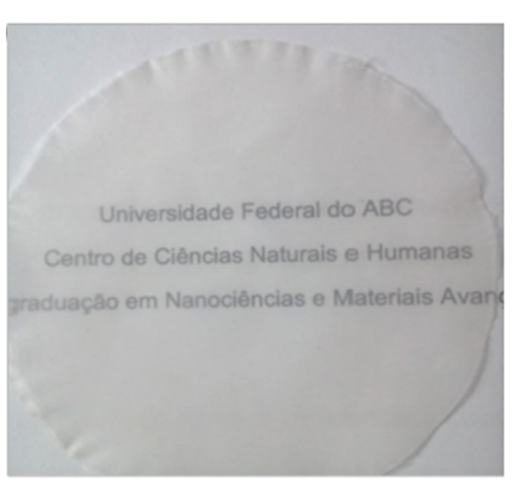

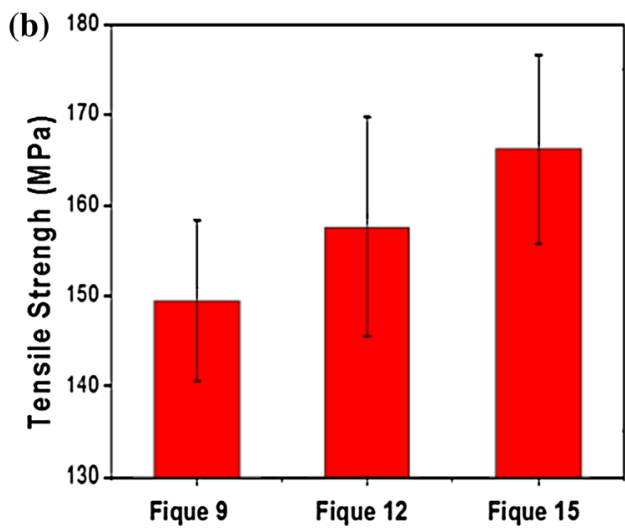


possible to optimize the process of preparation of fique nanofiber membranes to achieve even higher strengths.

The XRD patterns of raw macrofibers, bleached microfibers, and nanofibers are shown in Fig. 4. The crystallinity of cellulose was recognized early in X-ray diffraction studies, and the XRD patterns from native cellulose were assigned as Cellulose I [30]. Treating this native cellulose affects the XRD pattern; for example, regenerated and mercerized celluloses yield patterns referred to as Cellulose II [3]. The main peaks in all samples in Fig. 4 are typical of Cellulose I [30]: a narrow peak at $2 \theta=22^{\circ}$ and a smaller peak at $2 \theta=16^{\circ}$ associated with crystalline planes of [101] and [002] [13, 29], though there are small differences in width and intensity. The crystallinity index (CI) estimated from the XRD patterns was $77.3 \%$ for the bleached microfibers, $73.5 \%$ for the nanofibers, and $62.5 \%$ for the raw macrofibers. The highest CI for the bleached microfibers is due to a higher content of cellulose, since amorphous components, such as pectin, lignin, and hemicellulose, are eliminated from the raw macrofibers during bleaching. Furthermore, the alkali treatment was effective in removing most lignin content but did not convert Cellulose I into II, since no peak appears between $18^{\circ}$ and $22^{\circ}$ in the bleached microfibers and nanofibers [31]. The nanofibers had slightly lower CI owing to breaking of cellulose chains during the grinding process to reach the nanoscale. Indeed, a larger number of passes

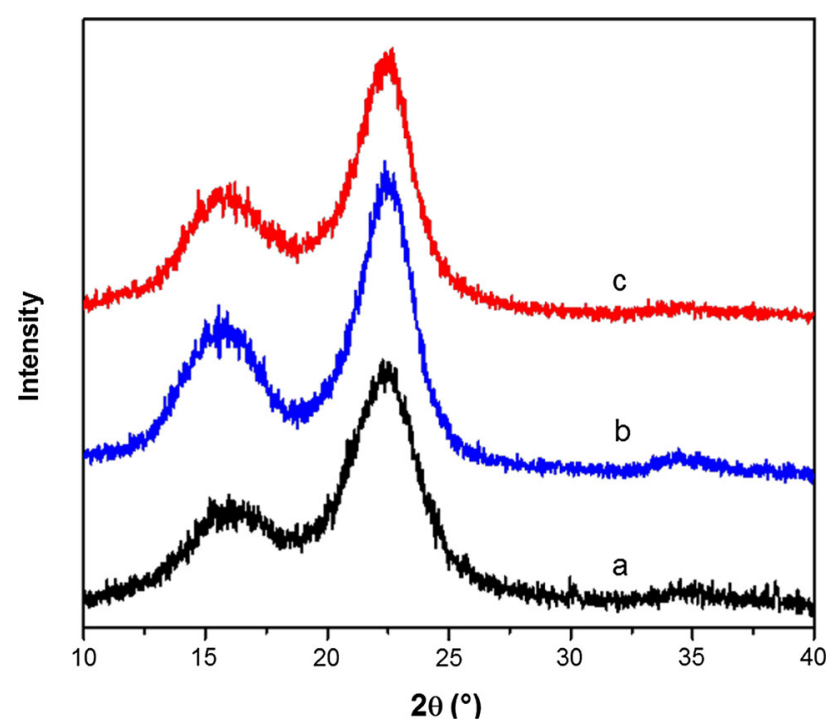

Figure 4 XRD patterns for raw fique macrofibers $(a)$, bleached microfibers $(b)$, and nanofibers grinded 15 times $(c)$. through the grinder has been reported to decrease the degree of crystallinity [12].

The FTIR spectra in Fig. 5 were used to identify the functional groups and understand changes induced by reaching the nanoscale in the fique macrofibers. All of the fibers displayed a band at $2900 \mathrm{~cm}^{-1}$ assigned to stretching vibrations of $\mathrm{C}-\mathrm{H}$ groups from cellulose and a broad band between 3300 and $3500 \mathrm{~cm}^{-1}$ (not shown in the figure) due to water molecules absorbed on the cellulose structure. The band at $890 \mathrm{~cm}^{-1}$ assigned to stretching of aliphatic groups on the carbohydrate chain has increased intensity in the bleached microfibers and nanofibers because of the removal of contaminant species [24, 32]. The bands at 1737 and at $1251 \mathrm{~cm}^{-1}$ appear mostly on the spectrum for the raw fique macrofibers, as they are assigned, respectively, to stretching of carbonyl groups $(\mathrm{C}=\mathrm{O})$ from lignin and hemicellulose and o-acetyl esters from hemicellulose, extractives, pectin, and lignin $[29,33,34]$. These results confirm that the bleaching process was efficient in removing lignin and hemicellulose; in particular, the spectrum for the nanofibers is similar to that of cellulose, with high-intensity bands at 890,1060 , and $1370 \mathrm{~cm}^{-1}$.

The effectiveness of the bleaching treatment was tested by calculating the kappa number, Fig 6, whose value is an indirect indication of the lignin content TAPPI. Since the higher the kappa number the higher the lignin content is, the values of $27.0 \pm 2.6$ and $2.7 \pm 2.6$ for raw macrofibers and nanofibers, respectively, indicate a decrease of approximately $90 \%$ of lignin content upon bleaching. Kappa number

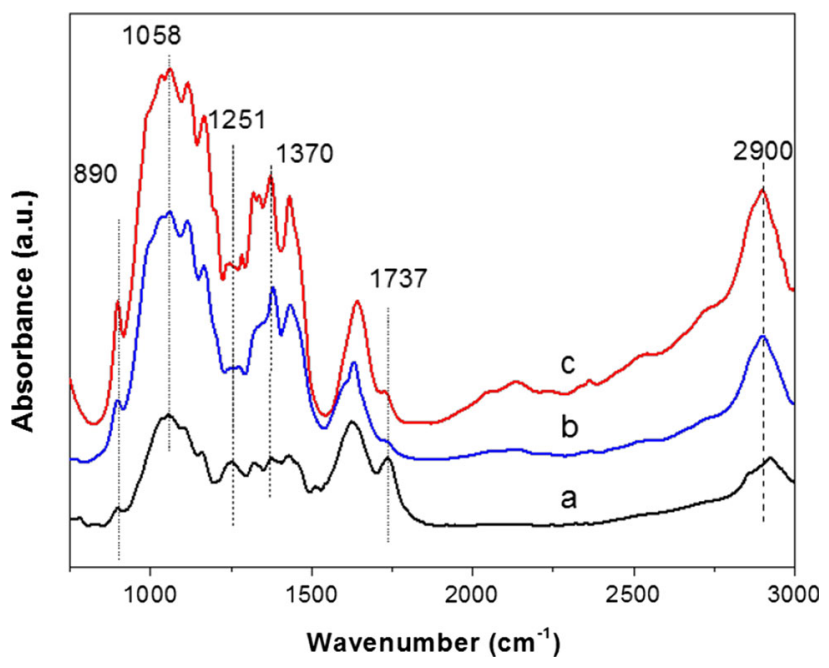

Figure 5 FTIR spectra taken with raw fique macrofibers (a), bleached microfibers $(b)$, and nanofibers $(c)$. 


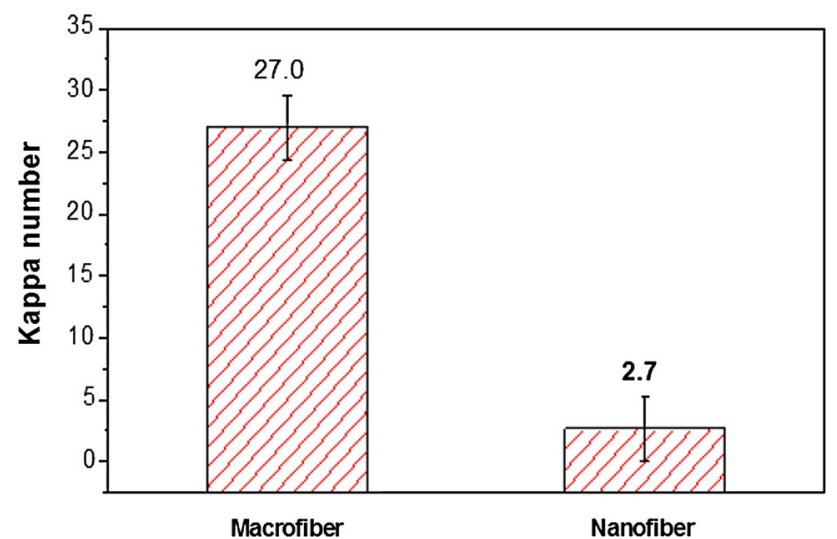

Figure 6 Kappa number for the raw macrofibers and nanofibers.

for the bleached microfibers was the same as for nanofibers, which shows that the mechanical process of grinding does not remove lignin from the matrix, as expected from the literature [24].

The thermogravimetric (TG) and differential thermogravimetric (DTG) curves shown in Fig. 7 allow us to investigate degradation and identify the material components based on the literature [35]. The TG curve for the bleached microfibers is shifted to higher temperatures, compared to the curve for the raw macrofibers, because bleaching turns the microfibers more resistant to degradation owing to the higher relative contents of the highly crystalline cellulose. The difference is better visualized in the DTG curves, where a shift in the peak for maximum degradation is observed from $364{ }^{\circ} \mathrm{C}$ for raw fibers to $380{ }^{\circ} \mathrm{C}$ for the bleached fibers. This peak is ascribed to degradation of cellulose [36]. Also to be noted are the additional features in the DTG curve for the raw macrofibers, with a shoulder at $301{ }^{\circ} \mathrm{C}$ owing to degradation of hemicellulose and a small peak at $497^{\circ} \mathrm{C}$ owing to lignin degradation [37]. As for the nanofibers, Fig. 7 shows that maximum degradation occurs at a lower temperature $\left(341^{\circ} \mathrm{C}\right)$, probably due to the shearing process that favors heat permeation in the nanoscale. Furthermore, the DTG curve is broader for the nanofibers because of the higher dispersion in dimensions for the nanofibrillated material.

\section{Biological assay}

\section{Indirect cytotoxicity-quantitative assay}

One important issue in the use of nanomaterials is related to the possible cytotoxicity, both during their production or upon their use. The first test of
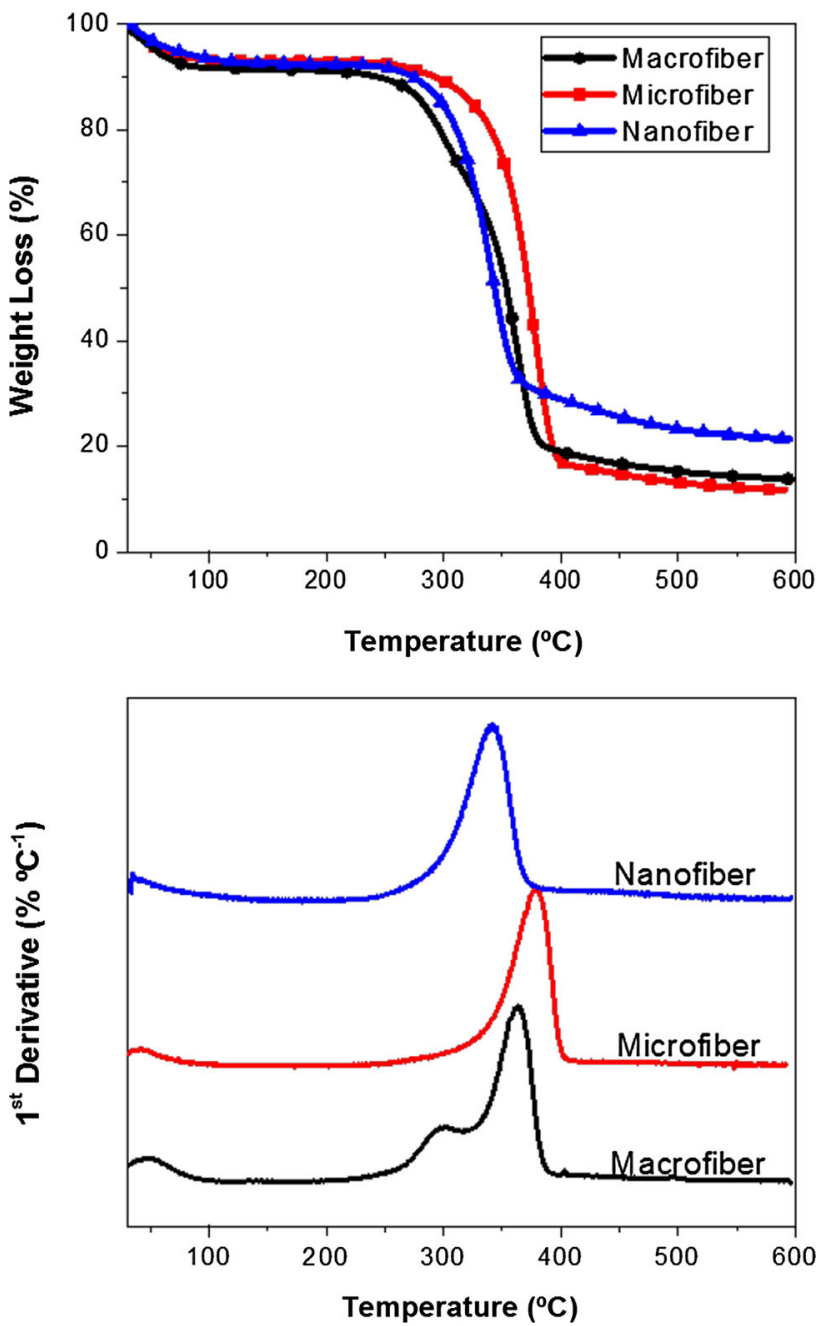

Figure 7 TG and DTG curves of raw macrofibers, bleached microfibers, and nanofibers.

biocompatibility can be performed with in vitro cytotoxicity studies [38-40], as is the case of the mitochondrial activity to quantify viable cells in the MTT assay [41, 42]. Figure 8 shows the Vero cell viability in an indirect cytotoxicity assay, using negative control as the pattern of $100 \%$ viable cells. The measurements showed similar pattern of cells cultured in the presence of nanofiber extracts compared to the non-cytotoxicity control, where the viable cells were around $109 \pm 25 \%$. The statistical analyses (One-way ANOVA) showed significant difference $(p<0.05)$ between negative and positive controls, and no significant difference was observed between negative control and the nanofibers. Therefore, the membranes made with nanofibers were considered not cytotoxic in this assay. 


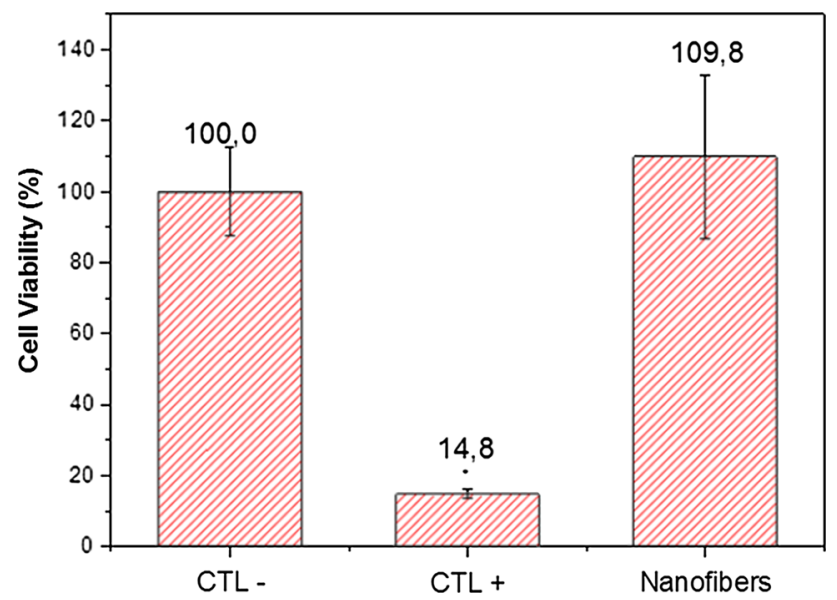

Figure 8 Cell viability with MTT assay and absorbance measurements. Negative control (CTL-) was considered as $100 \%$ viable cells. Positive control (CTL+) was obtained with $0.25 \%$ phenol. The cells cultured in the presence of cellulose nanofibers extract had $109.8 \%$ of viable cells.
The morphological evaluation of cytotoxicity is illustrated in Fig. 9, where the negative control (CTL-) with non-cytotoxic behavior shows a confluent monolayer of fibroblast cells. The positive, cytotoxic control (CTL+) was characterized by round, non-adhered cells in the presence of debris. The cells cultured in the presence of nanofibers extract showed a morphological pattern similar to the negative control cells, forming a confluent monolayer of spread cells. Also, the morphology and basic cell functions appear not to be affected by contact with the extract medium, since the morphology displays features of fibroblast cells. These morphological results corroborate the cellular activity (MTT) evidenced through the cell viability test, confirming that the nanofibers produced did not exhibit any cytotoxic behavior. Cellulose nanofibers from the wood of Pinus radiate, Eucalyptus nitens, and Eucalyptus globulus were not
Figure 9 Vero cells, morphological cytotoxicity assay. The live cell culture is shown on the left column and the toluidine blue-stained cells are shown on the right column. The positive control $(\mathrm{CTL}+)$ shows fewer rounded cells. The negative control (CTL-) shows elongated cell morphology in a monolayer. Cells cultured in the presence of NF show a morphological pattern similar to the negative control. This morphological observation confirms the quantitative assay for the noncytotoxic effects of the nanofibers.
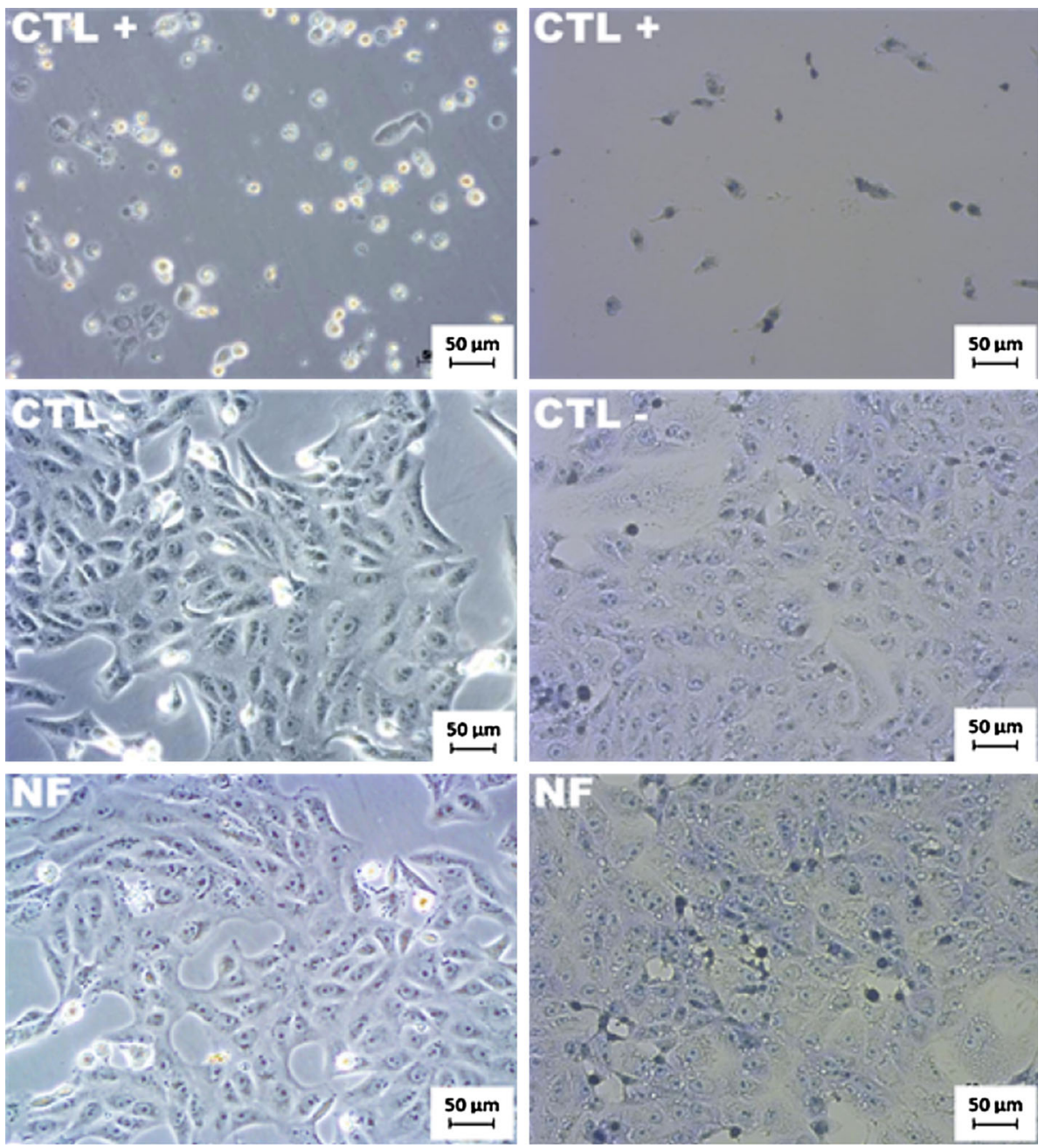
cytotoxic in direct and indirect contact assays [43]. Similar results were shown with cellulose nanofibers obtained from birch cellulose from kraft process, whereas microcrystalline cellulose did not show any effect on inflammatory system [44]. Cellulose nanowhiskers from bacteria were tested for cytotoxicity and no morphological alteration or genotoxicity was observed [45]. Since the cytotoxicity evaluation is the first test for any biocompatible material [46], the results presented here point to the nanofibers from fique crop as being promising materials.

\section{Conclusions}

Nanofibers from fique raw macrofibers could be obtained from bleached microfibers using grinding process, and the membranes made with the nanofibers were transparent. Bleaching caused the microfibers to resist to higher temperatures owing to the larger relative contents of crystalline cellulose in the bleached microfibers. The tensile strength of the nanofiber membranes increased with the number of grindings, though one may need to consider the increased cost with more energy being necessary with repeated grindings. From XRD patterns, we could infer that the macrofibers adopted a conformation typical of Cellulose I. The nanofibers seem to be biocompatible, judging by the cytotoxicity studies, since the mitochondrial activity was similar to the negative control, while the morphology was typical of the lineage used, with the cells expanding continuously.

\section{Acknowledgements}

This study was funded by CAPES/DFAIT (Grant Number 7604/13-0). S. F. SOUZA has received research scholarship grants from CAPES. The Staff at the Centre For Nanostructure Imaging from Department of Chemistry at University of Toronto are kindly recognized for their invaluable help and providing access to TEM. We are also thankful to the LNANO (Brazilian Nanotechnology National Laboratory at CNPEM, Campinas, Brazil) for SEM imaging under Proposal SEM - 19955.

\section{Compliance with ethical standards}

Conflict of interest The authors declare they have no conflict of interest.

\section{References}

[1] Dufresne A (2006) Comparing the mechanical properties of high performances polymer nanocomposites from biological sources. J Nanosci Nanotechnol 6(2):322-330

[2] Hussain F, Hojjati M, Okamoto M, Gorga RE (2006) Review article: polymer-matrix nanocomposites, processing, manufacturing, and application: an overview. J Compos Mater 40(17):1511-1575

[3] Atalla RH (1990) The structures of cellulose. In: MRS Proceedings, Cambridge Univ Press, p 89

[4] Trindade WG, de Paiva JMF, Leão AL, Frollini E (2008) Ionized-air-treated Curaua fibers as reinforcement for phenolic matrices. Macromol Mater Eng 293(6):521-528

[5] Cherian BM, Leão AL, de Souza SF, Costa LMM, de Olyveira GM, Kottaisamy M, Nagarajan E, Thomas S (2011) Cellulose nanocomposites with nanofibres isolated from pineapple leaf fibers for medical applications. Carbohydr Polym 86(4):1790-1798

[6] Dufresne A, Vignon MR (1998) Improvement of starch film performances using cellulose microfibrils. Macromolecules 31(8):2693-2696

[7] Nakagaito A, Yano H (2005) Novel high-strength biocomposites based on microfibrillated cellulose having nano-orderunit web-like network structure. Appl Phys A 80(1):155-159

[8] O'Sullivan AC (1997) Cellulose: the structure slowly unravels. Cellulose 4(3):173-207

[9] Jonoobi M, Mathew AP, Oksman K (2012) Producing lowcost cellulose nanofiber from sludge as new source of raw materials. Ind Crops Prod 40:232-238

[10] Bondeson D, Mathew A, Oksman K (2006) Optimization of the isolation of nanocrystals from microcrystalline cellulose by acid hydrolysis. Cellulose 13(2):171-180

[11] Penttilä PA, Várnai A, Pere J, Tammelin T, Salmén L, Siikaaho M, Viikari L, Serimaa R (2013) Xylan as limiting factor in enzymatic hydrolysis of nanocellulose. Bioresour Technol 129:135-141

[12] Iwamoto S, Nakagaito A, Yano H (2007) Nano-fibrillation of pulp fibers for the processing of transparent nanocomposites. Appl Phys A 89(2):461-466

[13] Panthapulakkal S, Sain M (2012) Preparation and characterization of cellulose nanofibril films from wood fibre and their thermoplastic polycarbonate composites. Int J Polym Sci 2012:6. doi:10.1155/2012/381342

[14] Hoyos CG, Alvarez VA, Rojo PG, Vázquez A (2012) Fique fibers: enhancement of the tensile strength of alkali treated fibers during tensile load application. Fibers Polym 13(5):632-640

[15] Ghali L, Msahli S, Zidi M, Sakli F (2009) Effect of pretreatment of Luffa fibres on the structural properties. Mater Lett 63(1):61-63 
[16] Mân Vu TH, Pakkanen H, Alén R (2004) Delignification of bamboo (Bambusa procera acher): part $1 \mathrm{kraft}$ pulping and the subsequent oxygen delignification to pulp with a low kappa number. Ind Crops Prod 19(1):49-57

[17] Denizot F, Lang R (1986) Rapid colorimetric assay for cell growth and survival: modifications to the tetrazolium dye procedure giving improved sensitivity and reliability. J Immunol Methods 89(2):271-277

[18] Ciapetti G, Cenni E, Pratelli L, Pizzoferrato A (1993) In vitro evaluation of cell/biomaterial interaction by MTT assay. Biomaterials 14(5):359-364

[19] Kalia S, Kaith B, Kaur I (2009) Pretreatments of natural fibers and their application as reinforcing material in polymer composites-a review. Polym Eng Sci 49(7):1253-1272

[20] Grew N (1965) 1682. The anatomy of plants. Johnson Reprint Corp, New York

[21] Dolmetsch HH, Dolmetsch H (1969) The fibrillar "bundling” of cellulose molecules in cotton1. Text Res J 39(6):568-584

[22] Heyn ANJ (1955) Small particle X-ray scattering by fibers, size and shape of microcrystallites. J Appl Phys 26(5):519-526

[23] Tucker P, George W (1972) Microfibers within fibers: a review. Polym Eng Sci 12(5):364-377. doi:10.1002/pen. 760120509

[24] Alemdar A, Sain M (2008) Isolation and characterization of nanofibers from agricultural residues - wheat straw and soy hulls. Bioresour Technol 99(6):1664-1671

[25] Souza SF, Leao AL, Cai JH, Wu C, Sain M, Cherian BM (2010) Nanocellulose from curava fibers and their nanocomposites. Mol Cryst Liq Cryst 522(1):342-352

[26] Corrêa A, de Morais Teixeira E, Pessan L, Mattoso L (2010) Cellulose nanofibers from curaua fibers. Cellulose 17(6):1183-1192. doi:10.1007/s10570-010-9453-3

[27] Gañán P, Mondragon I (2002) Surface modification of fique fibers. Effect on their physico-mechanical properties. Polym Compos 23(3):383-394. doi:10.1002/pc.10440

[28] Souza SF, Ferreira M, Sain M, Ferreira MZ, Pupo HF, Cherian BM, Leão AL (2015) 22-The use of curaua fibers as reinforcements in composites. In: Faruk O, Sain M (eds) Biofiber reinforcements in composite materials. Woodhead Publishing, Cambridge, pp 700-720

[29] Cheng S, Panthapulakkal S, Sain M, Asiri A (2014) Aloe vera rind cellulose nanofibers-reinforced films. J Appl Polym Sci. doi:10.1155/2014/903498

[30] Adel AM, El-Gendy AA, Diab MA, Abou-Zeid RE, ElZawawy WK, Dufresne A (2016) Microfibrillated cellulose from agricultural residues. Part I: Papermaking application. Ind Crop Prod 93(25):161-174

[31] Ass BA, Belgacem MN, Frollini E (2006) Mercerized linters cellulose: characterization and acetylation in N, N-dimethylacetamide/lithium chloride. Carbohydr Polym 63(1):19-29
[32] Siqueira G, Bras J, Dufresne A (2010) Luffa cylindrica as a lignocellulosic source of fiber, microfibrillated cellulose and cellulose nanocrystals. BioResources 5(2):727-740

[33] Kataoka Y, Kondo T (1999) Quantitative analysis for the cellulose I $\alpha$ crystalline phase in developing wood cell walls. Int J Biol Macromol 24(1):37-41

[34] Vazquez G, Antorrena G, Gonzalez J, Freire S (1997) FTIR, $1 \mathrm{H}$ and 13C NMR characterization of acetosolv-solubilized pine and eucalyptus lignins. Holzforschung-Int J Bio Chem Phys Technol Wood 51(2):158-166

[35] Yang H, Yan R, Chen H, Lee DH, Zheng C (2007) Characteristics of hemicellulose, cellulose and lignin pyrolysis. Fuel 86(12):1781-1788

[36] Morán JI, Alvarez VA, Cyras VP, Vázquez A (2008) Extraction of cellulose and preparation of nanocellulose from sisal fibers. Cellulose 15(1):149-159. doi:10.1007/ s10570-007-9145-9

[37] Monteiro SN, Calado V, Margem FM, Rodriguez RJ (2012) Thermogravimetric stability behavior of less common lignocellulosic fibers-a review. J Mater Res Technol 1(3):189-199

[38] Lombello CB, Malmonge SM, Wada MLF (2000) PolyHEMA and polyHEMA-poly(MMA-co-AA) as substrates for culturing vero cells. J Mater Sci 11(9):541-546. doi:10. 1023/A:1008915801187

[39] Malmonge S, Zavaglia CAdC, Santos Junior A, Wada M (1999) Avaliação da citotoxicidade de hidrogéis de polihema: um estudo in vitro. Res Biomed Eng 15(1-2):49-54

[40] Freshney RI (2005) Culture of specific cell types. Wiley Online Library, New York

[41] Wang F (2006) Culture of animal cells: a manual of basic technique. In Vitro Cell Dev Biol Anim 42(5):169

[42] Miller RR, McDevitt CA (1991) A quantitative microwell assay for chondrocyte cell adhesion. Anal Biochem 192(2):380-383

[43] Alexandrescu L, Syverud K, Gatti A, Chinga-Carrasco G (2013) Cytotoxicity tests of cellulose nanofibril-based structures. Cellulose 20(4):1765-1775

[44] Vartiainen J, Pöhler T, Sirola K, Pylkkänen L, Alenius H, Hokkinen J, Tapper U, Lahtinen P, Kapanen A, Putkisto K (2011) Health and environmental safety aspects of friction grinding and spray drying of microfibrillated cellulose. Cellulose 18(3):775-786

[45] Moreira S, Silva NB, Almeida-Lima J, Rocha HAO, Medeiros SRB, Alves C, Gama FM (2009) BC nanofibres: in vitro study of genotoxicity and cell proliferation. Toxicol Lett 189(3):235-241

[46] Freshney RI (2000) Culture of animal cells, a manual of basic technique. John Wiley and Sons inc 